WellBeing International

WBI Studies Repository

9-2009

\title{
People and Animals, Kindness and Cruelty: Research Directions and Policy Implications
}

Frank R. Ascione

University of Denver

Kenneth J. Shapiro

Animals and Society Institute

Follow this and additional works at: https://www.wellbeingintlstudiesrepository.org/acwp_awap

Part of the Animal Studies Commons, Other Anthropology Commons, and the Social Control, Law, Crime, and Deviance Commons

\section{Recommended Citation}

Ascione, F. R., \& Shapiro, K. (2009). People and animals, kindness and cruelty: Research directions and policy implications. Journal of Social Issues, 65(3), 569-587.

This material is brought to you for free and open access by WellBeing International. It has been accepted for inclusion by an authorized administrator of the WBI Studies Repository. For more information, please contact wbisr-info@wellbeingintl.org.

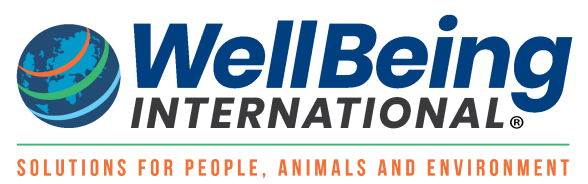


People and Animals, Kindness and Cruelty: Research Directions and Policy Implications

Frank R. Ascione

University of Denver Graduate School of Social Work and the American Humane Association

Kenneth Shapiro

Animals and Society Institute

\begin{abstract}
This article addresses the challenges of defining and assessing animal abuse, the relation between animal abuse and childhood mental health, the extensive research on animal abuse and intimate partner violence, and the implication of these empirical findings for programs to enhance human and animal welfare. Highlighted are recent developments and advances in research and policy issues on animal abuse. The reader is directed to existing reviews of research and areas of focus on the expanding horizon of empirical analyses and programmatic innovations addressing animal abuse. Following a discussion of forensic and veterinary issues related to animal abuse, we discuss policy issues including how the status of animals as human companions at times may place animals at risk. We also review developments in the field of human-animal relations and apply the primary-secondary-tertiary prevention public health model to prevention and treatment of animal abuse. We close with a description of community networks addressing animal abuse, interagency collaborations, and new developments in animal-related law.
\end{abstract}

Despite early allusions to nonhuman animal (hereafter, "animal") abuse in scholarly journals in psychology (e.g., Saunders \& Hall, 1900) and psychiatric texts (e.g., Pinel, 1809), the systematic, scientific study of humans' abuse of animals is a fairly recent phenomenon. Beginning with a seminal publication by Fernando Tapia in 1971, the literature on this topic has expanded dramatically and a number of academic reviews are now available. These include a compendium of previously published articles (Lockwood \& Ascione, 1998), a monograph of original chapters exploring the dimensions of animal abuse from varied professional perspectives (Ascione \& Arkow, 1999), and reviews of the literature examining animal abuse in the context of child maltreatment (Ascione, 2004, 2005b), other criminal acts (Gullone \& Clarke, 2008; Merz-Perez \& Heide, 2004), and intimate partner violence (Ascione, 2007; Carlisle-Frank \& Flanagan, 2006). An international handbook on animal abuse has been published (Ascione, 2008) and provides conceptual analyses, research reviews, and new empirical research on animal abuse (including hoarding and bestiality) from a variety of professional perspectives (e.g., veterinary science, social work, psychology and psychiatry, and law enforcement). We refer the reader to these sources for information primarily pertaining to articles published during the last quarter of the 20th century. Due to space limitations, in this article, we focus on selected examples of what is emerging on the horizon of the 21st century with regard to understanding and addressing animal abuse. 
We hope to build on the base of this accumulated knowledge and highlight recently published conceptual analyses and research studies that illustrate contemporary trends in our understanding of animal abuse. We will also suggest directions for further study and describe the ways that advances in our knowledge have influenced educational and therapeutic approaches, legislative change, and social policies designed to address animal abuse.

\section{Research Issues}

\section{Definition and Assessment}

Students of animal abuse often draw parallels to various forms of interpersonal violence perpetrated by humans. For our purposes, we define animal abuse as nonaccidental, socially unacceptable behavior that causes pain, suffering or distress to and/or the death of an animal. Acts of omission or commission encompassed by this definition could be applied to cases of child abuse and neglect, intimate partner violence, and maltreatment of elderly adults or adults with disabilities by substituting human victims for animal victims. In many ways, definitions of animal abuse are socially constructed (see, e.g., debates about the concept of "cruelty" in Nell, 2006) and may evolve as our understanding of the needs of animal's changes. Recently, McMillan (2005) focused attention on the emotional abuse of animals, a form of maltreatment that clearly falls within our definition but one that has yet to be systematically addressed in research. Empirical studies of animal abuse have often incorporated our definition or variants, but we do acknowledge that the definition may be considered a narrow one since conceptions of animal abuse beyond socially unacceptable behavior also warrant investigation (Munro, 2005).

Advances in a field of inquiry usually require advances in assessment and measurement. For many years, those of us interested in animal abuse, especially in childhood and adolescence, had to rely on existing instruments that queried respondents about this behavior. For example, there is 1 item, among over 100 items, that addresses animal abuse in Achenbach's (1991) Child Behavior Checklist, a widely used diagnostic instrument. The checklist is typically completed by a parent or guardian, and the teacherreport and self-report forms of the checklist do not include an animal abuse question. Obviously, relying on a single item for assessing animal abuse invites psychometric problems. Fortunately, a number of assessments specifically designed to measure animal abuse are now available. These include a parentreport questionnaire developed by Guymer, Mellor, Luk, and Pearse (2001), the parent-report and childself-report versions of the Cruelty to Animals Inventory (Dadds et al., 2004), the self-report form of the Childhood Trust Survey on Animal-Related Experiences (Boat, Loar, \& Phillips, 2008), surveys of animal abuse developed for use with Italian school children (P.E.T. Scale-Baldry, 2003; a questionnaire that includes socially unacceptable and socially "acceptable" animal abuse-Pagani, Robustelli, \& Ascione, 2007), and a survey designed for use in the context of domestic violence (Ascione et al., 2007). (Assessments of animal abuse in the context of elder abuse or abuse of disabled adults have not yet been developed-the first author and his collaborator, Terry Peak, are currently developing such assessment protocols.) Merz-Perez and Heide (2004) developed an assessment for retrospective reports of animal abuse (based on Ascione, Thompson, \& Black, 1997) for use with incarcerated men. The psychometric properties of most of these assessments are included in the citations listed above. 
As researchers continue to refine their methods of assessment, a number of challenges remain, especially when we attempt to determine the comparability of findings between studies.

- Are assessments based on parent/guardian reports or self-reports? The literature suggests that parents and guardians may not always be aware of their children's behavior, especially behavior away from the home environment (Dadds, Whiting, \& Hawes, 2006). Multisource assessments would be ideal.

- What forms of animal abuse do the assessments address and how are these forms defined? As with child maltreatment, we need to ask questions about physical, sexual, and emotional abuse of animals as well as animal neglect. The severity and frequency of incidents should be determined in addition to their first and most recent occurrence.

- How is the reliability of retrospective reports affected by the age of the respondent and by the time that has elapsed since the animal abuse was perpetrated?

- Are the reliability and accuracy of reports more easily assessed by incorporating measures of social desirability?

It is clear that for some research questions, dichotomous measures of animal abuse may be sufficient (e.g., relating the presence or absence of convictions for felony-level animal abuse to convictions for other criminal offenses, correlating hoarding with the presence of psychiatric disorders). However, our understanding of the etiologies, developmental trajectories, and predictive value of animal abuse histories for later psychological functioning will require both categorical and more dimensional measures. For example, recent work by Tallichet, Hensley, and Singer (2005) focuses on careful categorization of the forms that animal abuse may take. Examining the species of animals abused is also being studied (Tallichet, Hensley, O'Bryan, \& Hassel, 2005), an issue illustrating how defining animal abuse may be a more daunting task than defining maltreatment of humans.

One of the recent developments in assessing animal abuse involves the inclusion of questions about exposure to the maltreatment of animals. Such exposure may occur in the home, neighborhood, or other community settings but may also be present in various media (e.g., videos and Internet sites). Henry (2004a) examined the correlation of respondents' reported exposure to animal abuse ("whether they had ever witnessed an animal being tortured," p. 189) with self-reports by college students of their own perpetration of animal abuse. Self-reported animal abuse was three times higher for participants who had observed animal abuse. Thompson and Gullone (2006), studying adolescents, correlated such exposure ("Have you ever seen someone else hurt an animal on purpose?" p. 228) with self-reports of animal abuse and attitudes related to the humane treatment of animals. Self-reported perpetration of animal abuse was higher for adolescents exposed to animal abuse but exposure was not related to assessment of humane attitudes. Similar analyses appear in the studies by Baldry (2003) and Pagani et al. (2007). How such exposure may either desensitize the observer or heighten the observer's empathic responding is worthy of future study.

Examination of the correlations among various forms of violence in the family is one element of the LINK $^{\circledast}$ (see www.americanhumane.org)-a concept suggesting that animal abuse is, at times, related to forms of maltreatment involving human victims. The potential relations among different forms of family 
violence (child abuse, intimate partner violence, animal abuse, and abuse of elder adults) should foster greater multidisciplinary research attention the results of which could inform programs and policies for reducing violence in the family. We know that rates of animal abuse are higher in groups of abused children than in nonabused children, in samples of clinically distressed children than in normative samples, and in families experiencing intimate partner violence. These differences have been documented, but our understanding of the etiological factors related to these differences needs to be a higher research priority. One future direction for those examining the "link" is the study of the dynamics of the various ways that animal abuse may be implicated in interpersonal violence and the ways that understanding such dynamics could facilitate prevention and intervention (see later section on treatment issues).

\section{Relations to Clinical Psychology and Psychiatry}

The inclusion of animal abuse as one of the symptoms of conduct disorder (American Psychiatric Association, 2000) has facilitated increased attention to the maltreatment of animals. Subtypes of conduct disorder are now being examined, and one subtype that may be of special interest to those studying animal abuse relates to youths who are described as displaying callous and unemotional traits. These traits may be implicated in psychopathy (Vaughn \& Howard, 2005) and are potentially related to deficits in empathy (Kotler \& McMahon, 2005; Raine et al., 2006). In one study of a normative sample of school-aged children, Dadds et al. (2006) found that scores on a measure of callous-unemotional traits were positively correlated with scores on an animal abuse measure. A recent case report suggests that both actual and symbolic (e.g., dismembering a toy animal, hanging a sibling's toy teddy bear by a noose) animal abuse may have diagnostic value (Shapiro, Prince, Ireland, \& Stein, 2006).

Given the continuing scholarly interest in conduct disorder, it would be fruitful for scientists interested in animal abuse to collaborate with conduct disorder researchers who often study large samples of children at different ages, either cross-sectionally or longitudinally. If youths display the symptom of animal abuse as determined by dichotomous scoring resulting from diagnostic tests, follow-up assessment using more detailed measures (e.g., the assessment developed by Dadds et al., 2004) could be included. As the legitimacy and significance of studying animal abuse increase, we would hope that animal abuse will be integrated into more general study of the development of aggression, violence, and other antisocial behaviors (e.g., Stoff \& Susman, 2005).

Setting fires, bullying, and forced sex are three additional symptoms of antisocial behavior related to the diagnostic criteria for conduct disorder. Recent research suggests that animal abuse may co-occur with these other forms of destructiveness and aggression. Both Dadds and Fraser (2006) and Becker, Stuewig, Herrera, and McCloskey (2004) report correlations between arson and animal abuse in normative samples of children and in adolescents exposed to domestic violence, respectively. Given the comorbidity of fire setting and animal abuse, it may be of value to collaborate with researchers who study the etiology of fire setting and effective approaches to intervention (Kolko, 2002).

Similar collaboration with researchers interested in bullying may also be fruitful. Bullying includes repeated acts of aggression directed toward a less powerful victim (Smith, Pepler, \& Rigby, 2004), a 
definition that could easily be applied to the field of animal abuse. Baldry (2005), studying 9- to 12-yearold Italian schoolchildren, reports that being a victim of bullying at school (as distinct from other forms of victimization at school or at home) was the strongest predictor of perpetrating animal abuse. Similar results with a sample of 12- to 16-year-old Australian youths have been reported by Robertson and Gullone (2008) and suggest that bullying victimization and bullying perpetration are related to selfreported animal abuse.

Bestiality as a form of animal abuse is also now receiving greater attention than before (Beetz \& Podberscek, 2005). Elevated levels of sexual abuse of animals in youths residing in psychiatric hospitals and youths who were victims of sexual abuse have been reported by Ascione, Friedrich, Heath, and Hayashi (2003), and a recent case study illustrates the lethal form that animal sexual abuse may sometimes take (Hvozdík et al., 2006). A 46-year-old man admitted to sexually mutilating five 3-monthold calves, all of whom died from their injuries. After being apprehended, the man revealed that this was not his first episode of sexually assaulting animals. Bestiality has also been found to be related to crimes against humans when retrospective reports of incarcerated men have been examined (Hensley, Tallichet, \& Singer, 2006). Definition and assessment may be especially challenging when dealing with this phenomenon (Ascione, 2005a; Munro, 2006). Finally, although space limitations preclude our addressing animal hoarding, this form of maltreatment typically results in the neglect and abuse of large numbers of animals. The reader is referred to Patronek's $(2006,2008)$ recent reviews of our understanding of this phenomenon and its relation to human mental health issues.

\section{Animal Abuse and Intimate Partner Violence}

As noted earlier, a number of literature reviews have documented the prevalence of animal abuse, typically perpetrated by batterers, in homes suffering from domestic violence (Ascione, 2007; Strand \& Faver, 2005). These studies have focused on primarily Caucasian samples of women who were battered. A forthcoming report has extended this finding to a sample of Latina/Hispanic victims of domestic violence (Faver \& Cavazos, 2007). Allen, Gallagher, and Jones (2006) report on this phenomenon with a sample of women from the Republic of Ireland. Recent research has also demonstrated that children exposed to domestic violence are more likely than nonexposed children to have abused animals (Ascione et al., 2007; Currie, 2006; Duncan, Thomas, \& Miller, 2005).

Concern about pet welfare is sometimes an obstacle to victims of domestic violence seeking safety at domestic violence shelter. Collaboration between animal welfare and domestic violence agencies has attempted to remove this obstacle by offering pet sheltering for domestic violence victims (e.g., Ascione, 2000; Carlisle-Frank \& Flanagan, 2006), and there is an emerging trend to pass legislation including pets in orders of protection sought by domestic violence victims (Zorza, 2006). This remains one of the clearest examples of research on animal abuse being applied to changes in programmatic and social policy and will be discussed in a later section of this article. This legislative change and others related to animal abuse should be the subject of research within the legal profession (see, e.g., Frasch, 2008).

\section{Forensic and Veterinary Issues}


Forensic psychology and psychiatry are acknowledging the significance of assessing animal abuse in understanding psychopathy (Bower, 2006; Haden \& Scarpa, 2005), a development that will also be of interest to the legal profession (e.g., Schaffner, 2006). One study recently reported the discovery and apprehension, via DNA analysis, of a perpetrator who killed a protected wild animal (Lorenzini, 2005). Munro and Thrusfield (2001) alerted us to the issue of nonaccidental injuries in animals in the U.K., and a recently published text on veterinary forensic medicine (Sinclair, Merck, \& Lockwood, 2006) should facilitate the diagnosis of such injuries. (Munro and Thrusfield's work has recently been replicated in the Republic of Ireland by McGuinness, Allen, \& Jones, 2005.)

The issue of mandated reporting, by veterinarians, of suspected animal abuse is a topic of significant debate within the veterinary profession (Babcock \& Neihsl, 2006; Jack, 2005; Lofflin, 2006), a debate that is also emerging in the mental health community (Nelson, 2001). This debate includes concerns about confidentiality and the possibility that mandated reporting might reduce the likelihood of a pet owner seeking care for an injured animal (similar to concerns raised by pediatricians when mandated reporting of suspected child maltreatment was first proposed).

It is clear that basic and applied research on animal abuse is now informing changes in policies and programs, the subject to which we now turn our attention.

\section{Policy Issues}

Historically, the "link" is a by-product of the largely modern urban-based development that brought companion animals into the human family. This is more than a move from the barn or backyard to the parlor or TV room. Of those members of households in the United States that have companion animals (59\%; Gehrke, 1997), 87\% include their companion animal in the number of individuals in their home (Cohen, 2002). A considerable literature attests to the benefits of that inclusion for members of the family, human and animal (Garrity \& Stallones, 1998). However, membership has its privileges and benefits, but also its burdens and dangers.

A general systems approach applied to the study of the family readily shows that, like other institutions, it functions through a complex set of structures and processes: various alliances, styles of communication, boundaries between subsystems and other systems, and role assignments (Minuchin, 1974). As a member of this complex system, the family dog or cat has allies as well as enemies, open as well as closed lines of communication, and boundaries that appropriately maintain integrity and recognition of needs and interests as well as those that blur individual identity and result in exploitation and suffering. Dysfunctional family systems often include animal abuse as well as spousal, child, and elder abuse.

The co-occurrence of human violence and animal abuse within this "all in the family" context has spawned a wide range of policies and applications. In this section, we critically review existing and proposed policy innovations. To organize this extensive and broad-ranging set of policies and practices, we use, with some license, the distinction among levels of prevention popularized in the mental health community movement in the 1960s (Caplan, 1961). Primary prevention refers to efforts to reach the general population, before the onset of problems, and features education. Secondary prevention 
depends on the ability to recognize precursors to violent and other antisocial behavior toward human or animals and consists of preventative and remedial programs. Tertiary prevention involves major efforts at intervention and treatment of those already demonstrating substantial socially unacceptable and, often, illegal behavior.

\section{Primary Prevention: Education}

Some component of humane education has been a part of the traditional curriculum of grade and middle schools since the late 19th century (Grier, 2006). It has varied from a modest single presentation by the local humane society (dismissively referred to as "a dog and pony show") to a semester-long course; it often includes teaching care and responsibility for animals housed in the classroom. The addition to this curriculum of instruction and discussion of the link is a policy innovation of recent times and is part of a broader effort to incorporate humane issues in the general curriculum in various subjects. Thompson (2001) includes the link in her curriculum which she titles "Compassion Education Program: Creating a Society of Character" and frames in terms of character development. Another innovative curriculum combines the link with issues of social justice and environmental quality (Weil, 1999). Part of this effort is to professionalize the occupation of humane educator through degree programs and certification.

Turning to college and graduate studies, the emergence of the multidisciplinary field of Human-Animal Studies (HAS; aka "Animal Studies" and "Anthrozoology") provides an academically credible home for the studies of the link reviewed earlier. HAS is a metapolicy innovation as it is predicated on three propositions that foster recognition of the importance of the link: (1) we have socially constructed many types of animals - wild, feral, domesticated, companion, research model, commodities, cultural artifacts, and literary symbols; (2) the result is a myriad of relationships between human and animals varying along many dimensions-real/virtual, historical/contemporary, factual/fictional, and beneficial/detrimental; (3) the study of these manifold types of animals and contexts of human-animal interaction discovers and documents the pervasiveness and variety of interspecies relationships and their formative influence on our lives (Shapiro, 2007). Evidence of the growth and influence of the emerging field of HAS is found in direct products of scholarship ( journals, book series, conferences, and doctoral dissertations) and the development of institutional infrastructures that support that scholarship (courses, minors, majors, programs, university chairs, fellowships, think tanks, and sections or divisions of professional discipline organizations, such as the American Sociological and the American Psychological Associations).

The general implications of the field are that we should take animals, the abuse of animals, and animalhuman relationships seriously and develop policies and practices that maximize benefits and minimize costs to both parties. This often involves scholars uncovering the ways in which animals have been constructed or treated in their discipline to reveal the potential for more robust forms of human-animal relationships. In this way, HAS is comparable to fields that study other oppressed groups. For example, a feminist scholar deconstructs relationships involving women in history, fiction, and in current institutions to reveal the typically degraded role of women-how they have been objectified, reduced to sexual objects or help-mates, and denied full legal, economical, and political standing. Feminist studies 
and HAS play a role in the social justice movements dedicated to ending discrimination against the respective oppressed group.

Another important development in higher education that is a powerful instrument of policy innovation in the area of the link is the emergence over the past two decades of the field of Animal Law (AL). Again, evidence of its growth is found, mutatis mutandis, in devoted journals, conferences, courses, casebooks, and $A L$ sections of state and national bar associations. The field of $A L$ is in large part responsible for a number of judicial, legislative, and regulative developments that provide policy relevant to the link. These developments blur the lines between the three levels of prevention (primary, secondary, and tertiary) that we are using as a working organization of this article. In addition to their punitive and deterrent functions for at-risk and actual perpetrators, laws educate and shape the attitude of the general public regarding the importance of animal abuse and its relationship with other forms of violence.

Within the academic literature on the philosophy of law, scholars grapple with alternatives to the traditional legal classification of animals as property. The first and most radical is the argument that individuals of some animal species are "persons" as that concept is defined in law (Wise, 2000). Adoption of this standard would give "standing" to animals in court, entitling them to due process. A second and more conservative approach retains the frame of animals as property but provides within it the subclass of "sentient property" (Favre, 2004). Arguably, existing anticruelty statutes already imply a special status for animals as distinguished from, for example, artwork. That is, I am limited in my treatment of my dog in ways that I am not limited in my treatment of my Van Gogh painting. The recognition of animals as sentient property gives more explicit support to recent innovations such as (1) suing for wrongful injury and mental anguish in addition to the market value of an abused companion animal; and (2) including animals in domestic violence protective orders, so that an alleged perpetrator is restrained from approaching the animals as well as the humans in his or her family (Zorza, 2006). A third strategy applies more to the act of abuse than the legal status of the animal victim. This approach would reclassify animal abuse from a crime against property to a crime against society, like drug use, disorderly conduct, and, most relevant to the link, family offenses. Again, this classification would allow animal abuse to be taken more seriously in the context of criminal justice. These innovations support the recognition of the link in that they position human and animal abuse on the same or similar playing field.

Other legislative as well as social policy innovations that take animals and animal abuse more seriously include laws that restrict tethering of animals, instituting no-kill shelters, and protecting shelter workers from the burn-out and trauma of euthanizing animals. Part of the impetus for these policies is the HAS literature showing that humans who witness animal abuse are more likely both to become victims and perpetrators of abuse (Henry, 2004b).

Since 1990, the number of states in the United States that include felony provisions in their anticruelty statutes for at least the more egregious forms of animal abuse has increased from 7 to 42 . One model state anticruelty statute includes (1) distinctions based on the degree of abuse (cruel abuse, aggravated 
abuse, and torture); (2) hoarding (an apparently increasingly common and recalcitrant form of abuse); and (3) prohibitions against the depiction of animal cruelty (Illinois Humane Care for Animals Act, 1999).

Within the criminal justice system, another innovation in progress is an effort to include animal abuse as a distinct category in national data collection systems, such as the National Incident-Based Reporting System (formerly the FBI's Uniform Crime Report). The inclusion of animal abuse would alert local police and prosecutors to the importance of animal abuse, based, in part, on its role as an indicator of other delinquent and violent behavior.

\section{Secondary Prevention: At-Risk Populations}

For the purposes of this discussion, at-risk populations include individuals deemed likely to commit animal abuse, as well as those who already have done so but have not completed the link by also committing forms of violence or antisocial behavior toward humans. We also consider as at-risk, individuals who have perpetrated only one instance of animal abuse, particularly younger children, as the more robust findings in the link literature use recurrency as a measure of animal abuse. Secondary prevention only works if we can identify individuals at risk. As discussed earlier, researchers have developed several instruments, in various stages of validation and reliability.

Identification of populations at risk at an early age allows an opportunity for the more effective institution of preventative and remedial programs. Although the graduation hypothesis, the idea that animal abuse is a precursor of human abuse, has not been substantiated in the link literature, such a progression is described in the more general literature on antisocial and violent juvenile behavior. Furthermore, the robust findings of cooccurrence, as discussed earlier, reinforce the need for early identification of and intervention for at-risk populations, whether the second component of the link has occurred prior to, contemporaneous with, or after the occurrence of animal abuse. Finally, we do know that in the population diagnosed with childhood conduct disorder, animal abuse is a symptom that appears early in the development of that disorder (Miller, 2001). It is important, then, that we identify children at risk because of general factors associated with later antisocial and violent behavior (poverty, marginally functional families) and children at an early stage as perpetrators of animal abuse (isolated incident, occurrence before they are capable developmentally of culpability, or a low level of severity of the abuse; Randour, Krinsk, \& Wolf, 2002, p. 9).

Programs working with at-risk youth vary in duration and intensity. Through Forget-me-not Farm, a weekly after-school program, children from families and communities in which violence is prevalent learn the responsible care of animals (Rathman, 1999). PAL (People and Animals Learning; DeGrave, 1999) is a 3-week day camp for youth at risk that gives them experience in a wildlife rehabilitation center and an animal shelter. By feeding baby birds and training dogs to be obedient, they learn to be effective, nurturing, and responsible caregivers. Project Second Chance pairs teenage offenders with shelter dogs "to foster empathy, community responsibility, kindness, and an awareness of healthy social interactions" (Harbolt \& Ward, 2001, p. 179). The 3-week program results in a higher adoption rate for the dogs, compared to dogs who do not have this training, and anecdotal evidence suggests that the program is a positive learning experience for the juveniles (Harbolt \& Ward, 2001). 
Many of these programs are the products of networks established among various human service, criminal justice, educational, and humane societies and shelters. Forget-me-not Farm is a collaboration of the Humane Society of Sonoma County, the San Francisco Child Abuse Council, and the YWCA of Sonoma County (Rathman, 1999). The PAL program in Milwaukee is a result of the cooperative efforts of the District Attorney's office, the police department, the Commission on Domestic Violence and Sexual Assault, the Task Force on Family Violence, and other social service agencies (DeGrave, 1999). Many of these use animals as vehicles of learning and corrective socialization. However, to date, the evidence of the ameliorative effect of these animal-assisted activities and therapies is limited (Fine, 2000). Furthermore, concern has been raised about the welfare of the animals, as they are being exposed to children who are likely to or already have abused animals.

Operating largely at the level of secondary prevention, networking is itself a critical policy implication of the link. The co-occurrence of the various forms of domestic violence and the likely commonalities in the psychology of the perpetrators implies the importance of various community group stakeholders working together to identify potential perpetrators, and to develop preventative and ameliorative programs. These collaborations vary in the degree of formalization: from loose associations among individuals from various agencies to incorporated entities with their own staff (Arkow, 2003). Located in Portland, Maine, The Linkage Project is a nonprofit organization funded by foundations and corporations. Project collaborators include over a dozen agencies representing animal welfare, health and human services, education, corrections, domestic violence, public health, law enforcement, and medical interests. National animal advocacy organizations, such as the American Humane, the Humane Society of the United States, and the Animals and Society Institute provide workshops to help local communities build link-related networks.

These networks and the programs they develop include efforts to protect and rehabilitate victims, as well as to identify, and, where appropriate, prosecute and treat perpetrators. Cross-reporting and crosstraining have been instituted in many communities to teach human service personnel how to recognize and report perpetrators and victims of animal abuse and, conversely, to teach humane service personnel to recognize child, spousal, and elder abuse. Florida and San Diego County, California, mandate child protective personnel to report suspected animal abuse to humane agencies, and four states require animal care and control personnel to report possible child abuse to the appropriate human services (Arkow, 2003). Particularly in the involvement of therapists and veterinarians, this important policy innovation raises issues of confidentiality and liability. Increasingly, jurisdictions are addressing this issue, more often through providing protection against liability for breaking the confidentiality of client-provider relationships than through mandating reporting.

"Safe-havens" are cooperative arrangements, typically between women's shelters and humane shelters or veterinary facilities, that provide secure housing for companion animals frequently caught up in the dynamics of control, power, and intimidation that maintain spousal abuse (Carlisle-Frank \& Flanagan, 2006). Women's shelter personnel increasingly are including in their intake protocols inquiry about the involvement of companion animals in spousal or child abuse. Also, personnel are including consideration of the safety of companion animals in safety plans developed as early-warning systems that allow the current and prospective human victim to leave the scene of her or his immanent abuse. 
Summarizing, secondary prevention uses assessment instruments to identify people and animals at risk as either perpetrators or as victims. Community-based networks, some of which are formally constituted entities, develop a wide range of programs and policies aimed at providing interventions that prevent further animal abuse and reduce its likelihood of including human violence.

\section{Tertiary Prevention: Intervention and Treatment}

Twenty-seven states now include in their anticruelty statutes the provision for recommended or mandated counseling for convicted animal abusers. Significantly, these statutory provisions give status to mental health discourse by recognizing that animal abuse is understandable in terms of psychological concepts and findings. This reinforces the link and suggests the general strategy that policies and programs dealing with child and spousal abuse can be a model for those dealing with animal abuse. As spousal abuse gives rise to safety plans for escaping impending abuse, protective orders to prevent further abuse, and shelters to provide temporary refuge, so we now recognize the appropriateness and effectiveness of developing similar policies and programs to deal with animal abuse.

Mental health providers are beginning to realize the need to develop treatment models to work with convicted animal abusers, as well as with abusers referred by schools, physicians, and veterinarians. In fact, The AniCare Model of Treatment for Animal Abuse (Jory \& Randour, 1999), the first published treatment approach, was occasioned by the passage of the first such state law (California, 1998).

Persons presenting with the problem of animal abuse vary considerably in the degree of psychopathology, so that no one treatment is appropriate for all. Forms of animal abuse also vary from neglect to family-based abuse, to sadistically motivated and ritualized torture. The degree of suffering of the victim(s) is not necessarily correlated with the severity of the behavior from a psychological perspective. For example, neglect can produce prolonged suffering and death but can be perpetrated by an individual whose action is a combination of adoption of attitudes and behaviors of a particular subculture, subcultural influences, personal irresponsibility, and limited financial resources.

Beginning with the least intensive, we describe three available treatment modalities. (It should be noted that none of these have published outcome data.) The Strategic Humane Interventions Program (SHIP; Loar \& Colman, 2004) is also suitable for individuals at risk. It involves working with families one or more of whose members is at risk for or has perpetrated a violent behavior toward a human or animal. Using a technique based on operant conditioning, called clicker training, individual members of the family are directed in how to teach dogs at a shelter and each other more socially acceptable and responsible behavior. In effect, family members learn cognitive, empathic, and behavioral skills that are transferable to various settings and relationships. As an example of a training to shape a behavior of a family member, a child is helped to define a behavior that members of the family and the facilitator agree is a problem. Under the direction of the facilitator, the child then "shapes" the target behavior toward a more acceptable behavior. For example, a father is reinforced for using positive approaches rather than intimidation in his parenting of a child.

In an intermediate range of intervention, AniCare and AniCare Child (Randour et al., 2002) are approaches for working with adults and juveniles, respectively, presenting with the problem of animal 
abuse. They are designed for out-patient populations not diagnosed with major psychotic disorders and capable of benefiting from cognitive-behavioral interventions. Adapted from the intimate justice theory (Jory, Anderson, \& Greer, 1997), a model developed for clinical intervention with perpetrators of domestic violence, AniCare uses cognitive behavioral and gestalt techniques to deal with accountability, empathy, and problem-solving skills. AniCare Child uses cognitive behavioral, psychodynamic, and attachment theories to teach the child how to empathize with animals and develop more effective executive functions. It is adapted from components of the treatment of other related childhood presenting problems that have been found to be effective (Randour et al., 2002). A more direct formal evaluation of AniCare Child is in process. Finally, at the other extreme of intensity of intervention, Green Chimneys is a residential treatment program for disturbed youths, including but not limited to those who abuse animals (Ross, 1999). Children reside in the working farm for an extended period, during which they receive individual and group-based treatment, as well as animal-assisted therapy and activities.

\section{Conclusions}

The topic of animal abuse provides a surprisingly rich set of research opportunities. The demonstration of its association to other forms of abuse suggests an equally rich array of possible programs and policies. As we responded to the discovery of spousal and then child abuse, we turn to dealing with animal abuse- now with the clear view that these and other forms of violence are related to cause and resolution. We hope that this article has highlighted the vibrancy of scholarly research and the evolution of policy issues related to animal abuse. It is also our hope that a cadre of young professionals as well as seasoned scholars will be drawn to this subject and enhance its future development.

\section{References}

Achenbach, T. M. (1991). Manual for the Child Behavior Checklist/4 - 18 and 1991 profile. Burlington: University of Vermont Department of Psychiatry.

Allen, M., Gallagher, B., \& Jones, B. (2006). Domestic violence and the abuse of pets: Researching the link and its implications in Ireland. Practice, 18, 167 - 181.

American Psychiatric Association. (2000). Diagnostic and statistical manual of mental disorders (4th ed.). Washington, DC: Author.

Arkow, P. (2003). Breaking the cycles of violence. Alameda, CA: Latham Foundation.

Ascione, F. R. (2000). Safe havens for pets: Guidelines for programs sheltering pets for women who are battered. Logan, UT. From http://www.vachss.com/guest_dispatches/safe_havens.html.

Ascione, F. R. (2004). Children, animal abuse, and family violence-the multiple intersections of animal abuse, child victimization, and domestic violence. In K. A. Kendall-Tackett \& S. Giacomoni (Eds.), Victimization of children and youth: Patterns of abuse, response strategies (pp. 3.1 - 3.34). Kingston, NJ: Civic Research Institute. 
Ascione, F. R. (2005a). Bestiality: Petting, "humane rape," sexual assault, and the enigma of sexual interactions between humans and non-human animals. In A. M. Beetz \& A. L. Podberscek (Eds.), Bestiality and zoophilia: Sexual relations with animals (pp. $120-129$ ). West Lafayette, IN: Purdue University Press.

Ascione, F. R. (2005b). Children and animals: Exploring the roots of kindness and cruelty. West Lafayette, IN: Purdue University Press.

Ascione, F. R. (2007). Emerging research on animal abuse as a risk factor for intimate partner violence. In K. Kendall-Tackett \& S. Giacomoni (Eds.), Intimate partner violence (pp. 3.1 - 3.17). Kingston, NJ: Civic Research Institute.

Ascione, F. R. (Ed.). (2008). The international handbook of animal abuse and cruelty: Theory, research, and application. West Lafayette, IN: Purdue University Press.

Ascione, F. R, \& Arkow, P. (Eds.). (1999). Child abuse, domestic violence, and animal abuse: Linking the circles of compassion for prevention and intervention. West Lafayette, IN: Purdue University Press.

Ascione, F. R., Friedrich, W. N., Heath, J., \& Hayashi, K. (2003). Cruelty to animals in normative, sexually abused, and outpatient psychiatric samples of 6- to 12-year-old children: Relations to maltreatment and exposure to domestic violence. Anthrozoos, $16 *$, 194-212.

Ascione, F. R., Thompson, T. M., \& Black, T. (1997). Childhood cruelty to animals: Assessing cruelty dimensions and motivations. Anthrozoos, 10 * , 170-177.

Ascione, F. R., Weber, C. V., Thompson, T. M., Heath, J., Maruyama, M., \& Hayashi, K. (2007). Battered pets and domestic violence: Animal abuse reported by women experiencing intimate violence and by non-abused women. Violence against Women, 13, 354- 373.

Babcock, S. L., \& Neihsl, A. (2006). Requirements for mandatory reporting of animal cruelty. Journal of the American Veterinary Medical Association, 228, 685 - 688.

Baldry, A. C. (2003). Animal abuse and exposure to interparental violence in Italian youth. Journal of Interpersonal Violence, 18, 258- 281.

Baldry, A. C. (2005). Animal abuse among preadolescents directly and indirectly victimized at school and at home. Criminal Behaviour and Mental Health, 15, 97-110.

Becker, K. D., Stuewig, J., Herrera, V. M., \& McCloskey, L. A. (2004). A study of firesetting and animal cruelty in children: Family influences and adolescent outcomes. Journal of the American Academy of Child and Adolescent Psychiatry, 43, 905 - 912.

Beetz, A. M., \& Podberscek, A. L. (Eds.). (2005). Bestiality and zoophilia: Sexual relations with animals. West Lafayette, IN: Purdue University Press. 
Boat, B. W., Loar, L., \& Phillips, A. (2008). Collaborating to assess, intervene, and prosecute animal abuse: A continuum of protection for children and animals. In F. R. Ascione (Ed.), International handbook of animal abuse and cruelty: Theory, research, and application (pp. $393-422$ ). West Lafayette, IN: Purdue University Press.

Bower, B. (2006). The predator's gaze: Scientists explore the frightening world of psychopaths. Science News Online, 170(24). Retrieved February 26, 2007, from http://www.sciencenews.org.

California Anti-Cruelty Statute. (1998). SB1991.

Caplan, G. (1961). An approach to community mental health. New York City: Grune and Stratton.

Carlisle-Frank, P., \& Flanagan, T. (2006). Silent victims: recognizing and stopping abuse of the family pet. Lanham, MD: University Press of America.

Cohen, S. P. (2002). Can pets function as family members? Western Journal of Nursing Research, 24, 621 -638 .

Currie, C. L. (2006). Animal cruelty by children exposed to domestic violence. Child Abuse and Neglect, $30,425-435$.

Dadds, M. R., \& Fraser, J. A. (2006). Fire interest, fire setting and psychopathology in Australian children: A normative study. Australian and New Zealand Journal of Psychiatry, 40, 581 - 586.

Dadds, M. R., Whiting, C., Bunn, P., Fraser, J. A., Charlson, J. H., \& Pirola-Merlo, A. (2004). Measurement of cruelty in children: The Cruelty to Animals Inventory. Journal of Abnormal Child Psychology, 32, 321 334.

Dadds, M. R., Whiting, C., \& Hawes, D. J. (2006). Associations among cruelty to animals, family conflict, and psychopathic traits in childhood. Journal of Interpersonal Violence, 21, 411- 429.

DeGrave, J. (1999). People and animals learning: The PAL program. In F. Ascione \& P. Arkow (Eds.), Child abuse, domestic violence, and animal abuse (pp. 410 - 423). West Lafayette, IN: Purdue University Press.

Duncan, A., Thomas, J. C., \& Miller, C. (2005). Significance of family risk factors in development of childhood animal cruelty in adolescent boys with conduct problems. Journal of Family Violence, 20, 235 $-239$.

Faver, C. A., \& Cavazos, A. M., Jr. (2007). Animal abuse and domestic violence: A view from the border. Journal of Emotional Abuse, 7, 59-81.

Favre, D. (2004). Integrating animal interests into our legal system. Animal Law, 10, 87 - 98

Fine, A. (2000). Handbook on animal-assisted therapy: Theoretical foundations and guidelines for practice. Burlington, MA: Academic Press. 
Frasch, P. D. (2008). The impact of improved American anti-cruelty laws in the investigation, prosecution, and sentencing of abusers. In F. R. Ascione (Ed.), The international handbook of animal abuse and cruelty: Theory, research, and application (pp. 59 - 86). West Lafayette, IN: Purdue University Press.

Garrity, T. F., \& Stallones, L. (1998). Effects of pet contact on human well-being: Review of recent research. In C. C. Wilson \& D. C. Turner (Eds.), Companion animals in human health (pp. 3-22). Thousand Oaks, CA: Sage.

Gehrke, B. (1997). Results of AVMA survey of U.S. pet-owning households on companion animal ownership. Journal of the American Veterinary Medical Association, 211, 169.

Grier, K. (2006). Pets in America: A history. Chapel Hill: University of North Carolina University Press.

Gullone, E., \& Clarke, J. P. (2008). Animal abuse, cruelty, and welfare: An Australian perspective. In F. R. Ascione (Ed.), The international handbook of animal abuse and cruelty: Theory, research, and application (pp. 305 - 334). West Lafayette, IN: Purdue University Press.

Guymer, E. C., Mellor, D., Luk, E. S. L., \& Pearse, V. (2001). The development of a screening questionnaire for childhood cruelty to animals. Journal of Child Psychology and Psychiatry, 42, 1057 1063.

Haden, S. C., \& Scarpa, A. (2005). Childhood animal cruelty: A review of research, assessment, and therapeutic issues. The Forensic Examiner, 14, $23-32$.

Harbolt, T, \& Ward, T. (2001). Teaming incarcerated youth with shelter dogs for a second chance. Society and Animals, 9(2), $177-182$.

Henry, B. C. (2004a). Exposure to animal abuse and group context: Two factors affecting participation in animal abuse. Anthrozoos, $17{ }^{*}, 290-305$.

Henry, B. C. (2004b). The relationship between animal cruelty, delinquency, and attitudes toward the treatment of animals. Society and Animals, 12, 185- 207.

Hensley, C., Tallichet, S. E., \& Singer, S. D. (2006). Exploring the possible link between childhood and adolescent bestiality and interpersonal violence. Journal of Interpersonal Violence, 21, 910 - 923.

Hvozdík, A., Bugarský, A., Kottferová, J., Vargová, M., Ondrašovičová, O., Ondrašovič, M., \& Sasáková, N. (2006). Ethological, psychological and legal aspects of animal sexual abuse.' The Veterinary Journal, 172, $374-376$.

Illinois Humane Care for Animals Act. (1999). 510 ILCS 70/

Jack, D. C. (2005). "Good samaritans": A legislative solution for mandatory reporting of suspected animal abuse. Canadian Veterinary Journal, 46, $539-540$. 
Jory, B., Anderson, D., \& Greer, C. (1997). Intimate justice: Confronting issues of accountability, respect, and freedom in treatment for abuse and violence. Journal of Marital and Family Therapy, 23, 399 - 419.

Jory, B., \& Randour, M. (1999). The AniCare model of treatment for animal abuse. Washington Grove, MD: Psychologists for the Ethical Treatment of Animals.

Kolko, D. (Ed.). (2002). Handbook on firesetting in children and youth. New York: Academic.

Kotler, J. S., \& McMahon, R. J. (2005). Child psychopathy: Theories, measurement, and relations with development and persistence of conduct problems. Clinical Child and Family Psychology Review, 8, 291 -325 .

Loar, L., \& Colman, L. (2004). Teaching empathy: Animal-assisted therapy programs for children and families exposed to violence. Alameda, CA: Latham Foundation.

Lockwood, R., \& Ascione, F. (Eds.). (1998). Cruelty to animals and Interpersonal Violence: Readings in research and application. West Lafayette, IN: Purdue University Press.

Lofflin, J. (2006). Animal abuse: What practitioners need to know. Veterinary Medicine, 101, 506 - 518.

Lorenzini, R. (2005). DNA forensics and the poaching of wildlife in Italy: A case study. Forensic Science International, 153, 218-221.

McGuinness, K., Allen, M., \& Jones, B. R. (2005). Non-accidental injury in companion animals in the Republic of Ireland. Irish Veterinary Journal, 58, $392-396$.

McMillan, F. D. (2005). Emotional maltreatment in animals. In F. D. McMillan (Ed.), Mental health and well-being in animals (pp. 167 -179). Ames, IA: Blackwell.

Merz-Perez, L., \& Heide, K. M. (2004). Animal cruelty: Pathway to violence against people. Walnut Creek, CA: AltaMira.

Miller, C. (2001). Childhood animal cruelty and interpersonal violence. Clinical Psychology Review, 21, $735-749$.

Minuchin, S. (1974). Families and family therapy. Cambridge: Harvard University Press. Munro, J. (2005). Confronting cruelty: Moral orthodoxy and the challenge of the animal rights movement. Leiden, The Netherlands: Brill.

Munro, H. M. C. (2006). Animal sexual abuse: A veterinary taboo? The Veterinary Journal, 172, 195 197.

Munro, H. M. C., \& Thrusfield, M. V. (2001). "Battered pets": Features that raise suspicion of nonaccidental injury. Journal of Small Animal Practice, 42, $218-226$.

Nell, V. (2006). Cruelty's rewards: The gratifications of perpetrators and spectators. Behavioral and Brain Sciences, 29, $211-224$. 
Nelson, P. (2001). A survey of psychologists' attitudes, opinions, and clinical experiences with animal abuse. Unpublished doctoral dissertation, Wright Institute Graduate School of Psychology, Berkeley, CA.

Pagani, C., Robustelli, F., \& Ascione, F. R. (2007). Italian youths' attitudes toward and concern for animals. Anthrozoos, 20 " , 275-293.

Patronek, G. J. (2006). Animal hoarding: Its roots and recognition. Veterinary Medicine, 101, 520 - 530.

Patronek, G. (2008). Animal hoarding: A third dimension of animal abuse. In F. R. Ascione (Ed.), The international handbook of animal abuse and cruelty: Theory, research, and application (pp. 221 - 246). West Lafayette, IN: Purdue University Press.

Pinel, P. (1809). Traité médico-philosophique de la aliéntation mentale (2nd ed.). Paris: Brosson. Raine, A., Dodge, K., Loeber, R., Gatzke-Kopp, L., Lynam, D., Reynolds, C., Stouthamer-Loeber, M., \& Liu, J. (2006). The Reactive-Proactive Aggression Questionnaire: Differential correlates of reactive and proactive aggression in adolescent boys. Aggressive Behavior, 32, 159- 171.

Randour, M., Krinsk, S., \& Wolf, J. (2002). AniCare child: An assessment and treatment approach for childhood animal abuse. Washington Grove, MD: Psychologists for the Ethical Treatment of Animals.

Rathman, C. (1999). Forget me not farm: Teaching gentleness with gardens and animals to children from violent homes and communities. In F. Ascione \& P. Arkow (Eds.), Child abuse, domestic violence, and animal abuse (pp. 393 - 409). West Lafayette, IN: Purdue University Press.

Robertson, N., \& Gullone, E. (2008). The relationship between bullying and animal cruelty behaviours in Australian adolescents. Journal of Applied Developmental Psychology, 29, 371 - 379.

Ross, S. (1999). Green Chimneys: We give troubled children the gift of giving. In F. Ascione \& P. Arkow (Eds.), Child abuse, domestic violence, and animal abuse (pp. $367-379)$. West Lafayette, IN: Purdue University Press.

Saunders, F. H., \& Hall, G. S. (1900). Pity. American Journal of Psychology, 11, $534-591$.

Schaffner, J. E. (2006). Animal law at GW: Linking domestic violence, child abuse, and animal cruelty. ABA TIPS Animal Law Committee Newsletter, Winter Issue. Retrieved April 9, 2007, from http://www.law.gwu.edu

Shapiro, H. L., Prince, J. B., Ireland, R., \& Stein, M. T. (2006). A dominating imaginary friend, cruelty to animals, social withdrawal, and growth deficiency in a 7-year-old girl with parents with schizophrenia. Journal of Developmental and Behavioral Pediatrics, 27, $231-236$.

Shapiro, K. (2007). Human-animal studies: Growing the field, applying the field. Baltimore: Animals and Society Institute.

Sinclair, L., Merck, M., \& Lockwood, R. (Eds.). (2006). Forensic investigation of animal cruelty: A guide for veterinary and law enforcement professionals. Washington, DC: Humane Society Press. Smith, R. K., 
Pepler, D., \& Rigby, K. (Eds.). (2004). Bullying in schools: How successful can interventions be? Cambridge, U.K.: Cambridge University Press.

Stoff, D. M., \& Susman, E. J. (Eds.). (2005). Developmental psychobiology of aggression. Cambridge, U.K.: Cambridge University Press.

Strand, E. B., \& Faver, C. A. (2005). Battered women's concern for their pets: A closer look. Journal of Family Social Work, 9, $39-58$.

Tallichet, S. E., Hensley, C., O’Bryan, A., \& Hassel, H. (2005). Targets for cruelty: Demographic and situational factors affecting the type of animal abused. Criminal Justice Studies, 18, $173-182$.

Tallichet, S. E., Hensley, C., \& Singer, S. D. (2005). Unraveling the methods of childhood and adolescent cruelty to nonhuman animals. Society and Animals, 13, $91-107$.

Tapia, F. (1971). Children who are cruel to animals. Child Psychiatry and Human Development, 2, 70 77.

Thompson, C. B. (2001).Compassion education program: Creating a society of character. Orangeburg, SC: The Healing Species.

Thompson, K. L., \& Gullone, E. (2006). An investigation into the association between the witnessing of animal abuse and adolescents' behavior toward animals. Society and Animals, 14, $221-243$.

Vaughn, M. G., \& Howard, M. O. (2005). The construct of psychopathy and its potential contribution to the study of serious, violent, and chronic youth offending. Youth Violence and Juvenile Justice, 3, 235 252.

Weil, Z. (1999). Sowing seeds workbook: A humane education primer. Surry, ME: Center for Compassionate Living.

Wise, S. (2000). Rattling the cage: Toward legal rights for animals. New York City: Perseus. Zorza, J. (2006). Maine's encouraging law protecting animals in domestic violence situations. Domestic Violence Report, 11, 65 and 78. 